\title{
EAl Endorsed Transactions

\section{Design, Simulation and Economic Analysis of A Rooftop Solar PV System in Vietnam}

\author{
Thanh Ba Nguyen ${ }^{1, *}$, Phuong Hoang Van ${ }^{1}$ \\ ${ }^{1}$ Institute of Engineering and Technology, Thu Dau Mot University, Thu Dau Mot City, 75109, Vietnam
}

\begin{abstract}
Installing a grid-connected rooftop solar system for a household is an important issue; therefore, there are many factors that need to be considered before the installation is decided. The main factors to be noted are the total cost of the installation, the amount of electricity generated as well as the government's support policies for the development of solar energy. This article presents the design, simulation and economic analysis of an $8.36 \mathrm{kWp}$ grid-connected rooftop solar power project for a household in Thu Dau Mot City, Vietnam. The study calculates the generated electricity, the efficiency of the Photovoltaic (PV) power system, the ability to reduce the amount of $\mathrm{CO}_{2}$ emitted into the environment and the economic indicators of the project. This research is useful for stakeholders investing in residential rooftop solar PV systems and Vietnam's energy policymakers as well.
\end{abstract}

Keywords: Rooftop Solar, Grid Connected PV System, Economic Evaluation, Energy System Analysis.

Received on 18 December 2020, accepted on 25 January 2021, published on 27 January 2021

Copyright (C) 2021 Thanh Ba Nguyen et al., licensed to EAI. This is an open access article distributed under the terms of the Creative Commons Attribution license, which permits unlimited use, distribution and reproduction in any medium so long as the original work is properly cited.

doi: 10.4108/eai.27-1-2021.168504

\section{Introduction}

The exploitation of environmentally friendly renewable energy sources has been the world's essential issue in recent years $[1,2]$. Scientists and engineers around the world are actively involved in the development of alternative energy sources. The most common of them are converted into electrical energy, including wind energy [3]; kinetic energy of water flow (river) [4]; energy of sea tides; kinetic energy of pressing $[5,6]$ and solar electromagnetic radiation [7].

Among these energy sources, solar radiation is an extremely important one in Vietnam $[2,8]$. On average, the total solar radiation in Vietnam is about $5 \mathrm{~kW} / \mathrm{h} / \mathrm{m}^{2} /$ day in the central and southern provinces, and $4 \mathrm{~kW} / \mathrm{h} / \mathrm{m}^{2} /$ day in the northern provinces; the number of sunny hours per year in the Northern Vietnam is 1500-1700 hours while in the Central and Southern Vietnam it is about 2000-2600 hours per year $[9,10]$. Realizing such a huge potential, Vietnam has issued the renewable energy development strategy up to 2050, including rooftop solar power [11]. In particular, the Decision No. 13/2020/QD-TTg, issued by the Prime Minister of the Government, created a clear and strict legal corridor for rooftop solar power buyers and sellers as well as encourages more people and businesses to invest in rooftop solar power projects [12].

The application of design and simulation software for the purpose of exploiting solar power is also an inevitable trend of the world. Currently, many research institutes and solar cell manufacturers have been developing the software such as PVsyst [13], Solar Pro [14], Sunny Design [15], PV*SOL [16], etc. As a result, there are a large number of studies on evaluating and analysing rooftop solar energy as follows:

S.K. Kyprianou et al. [17] conducted a feasibility study of a 50kWp photovoltaic park in Cyprus. The performance of the PV system was simulated by the PVsyst software and the economic factors were evaluated by using a tool designed by the Cyprus Institute of Energy.

*Corresponding author. Email: thanhnb@tdmu.edu.vn 
Paras Karki et al. [18] presented a study on comparing the efficiency of $60 \mathrm{~kW}$ photovoltaic systems in Kathmandu and Berlin by using PVsyst. The author evaluated the energy generated and losses in the two cities by using the simulation software.

Sharma, V., and Chandel, S.S. [19] analysed the efficiency of the first $190 \mathrm{kWp}$ grid-connected solar photovoltaic plant installed in India. The result showed that the estimated amount of electricity is almost similar to the measured productivity of the solar power plant.

Al Ali, M., and Emziane, M. [20] evaluated the performance of seven different PV systems. The study showed that rooftop solar PV efficiency in Abu Dubai is feasible.

Mounir Bouzguenda et al. [21] designed, simulated and analysed an independent solar power system at King Faisal University. In this study, shading problem was analysed and it is shown that it had a little effect on the system performance.

Priya Yadav et al. [22] presented simulation results of $1 \mathrm{kWp}$ solar power system by using PVsyst for Hamirpur, India. Efficiency ratio was $72.4 \%$ and produced energy and system losses were also simulated.

An independent photovoltaic system was simulated by Y. M. Irwan et al. [23] by using PVsyst software. The annual energy of the system obtained is $841.31 \mathrm{kWh} /$ year.

Okello, D. et al. [24] analysed the performance of a $3.2 \mathrm{kWp}$ rooftop solar project in Port Elizabeth, South Africa and compared the simulation results with actual measurements, showing the similar values.

Tarigan, E. et al. [25] performed an economic and technical assessment of an $1 \mathrm{kWp}$ residential rooftop solar PV project in Surabaya, Indonesia by using software PVsyt and RETScreen. The result showed that in terms of technology the system could meet the household's basic demand, however the payback period was long, 17.6 years.

Matiyali, K., \& Ashok, A. [26] conducted a study on the efficiency of a $400 \mathrm{kWp}$ grid-connected solar power system installed in Dhalipur by using PVsyst software. The simulation results showed that the performance ratio was $78.1 \%$, the generated electricity ranged from 3.14 $\mathrm{kWh} / \mathrm{kWp} /$ day to $5.65 \mathrm{kWh} / \mathrm{kWp} /$ day.

Ashwini, K. et al. [27] evaluated a $100 \mathrm{kWp}$ rooftop solar PV system installed at Poornima University, Jaipur, India. The simulation was performed by PVsyst software, the evaluated values included reference yield, final yield, energy injected to grid and performance ratio.

Sharma, R., and Gidwani, L. [28] used PVSOL software to simulate a $234 \mathrm{~kW}$ solar power system, the research shows that the system can generate enough electrical energy for consumption and reduce energy consumption from the grid as well as reduce the dependence on the grid. Financial analysis of this system by assuming some indicators was also performed in this study.

In a simulation project of a $100 \mathrm{kWp}$ grid-connected solar power system, Kumar, N. M., Kumar et al. [29] used PVsyst simulation software and the weather data
Meteonorm 7.1. It is showed that the annual energy generated is $165.38 \mathrm{MWh}$ and the performance rate is $80 \%$.

Vineet Mediratta et al. [30] analysed and designed a grid-connected PV system in Zirakpur (Punjab) with the latitude of $30.40^{\circ} \mathrm{N}$ and the longitude of $76.50^{\circ} \mathrm{E}$. The author used PVsyst software and measured the parameters such as maximum power, solar radiation, angle of inclination and loss of the system.

Dondariya, C. et al. [31] simulated the rooftop solar PV system by using PV*SOL, PVGIS, SolarGIS and SISIFO software. Research results showed that PVSOL software is rated the most reliable.

Korsavi, S. S. et al. [32] evaluated the economic and energy efficiency of 14 rooftop solar power projects in two climatic regions of Iran. The assessment was based on both simulation results and actual measurements. The actual measurement data were used to calculate economic indicators of projects such as pay-back period (PBP), net present value (NPV), return of investment (ROI) and levelized cost of energy (LCOE).

Elamim, A. et al. [33] evaluated the efficiency of a $5.94 \mathrm{kWp}$ system with three types of PV panels (a-Si, pc-Si and mc-Si) in the city of Errachidia, Morocco. The results showed that the highest values in terms of daily final yield, capacity factor, performance ratio, levelised cost of electricity and payback time were recorded by pc-Si solar module.

Akpolat, A. N. et al. [34] used PVSOL software to perform a simulation study for a project at Marmara University in Istanbul, Turkey. Simulation results showed that the $84.75 \mathrm{kWp}$ rooftop solar power system gave positive results.

Kumar, N. M. et al. [35] used PVsyst software to simulate and predict the efficiency and losses of a $200 \mathrm{~kW}$ rooftop solar system installed at IRB Complex-5, Chandigarh, in the North of India. The annual energy obtained was $292954 \mathrm{kWh}$; losses were $26.5 \%$.

Dey, D., \& Subudhi, B. [36] designed, simulated and economically evaluated a $90 \mathrm{kWp}$ grid connected solar power project at National Institute of Technology (NIT) Rourkela, Odisha, India. The simulation was performed by PVsyst 6.70 software; the cost of the PV system and the amount of $\mathrm{CO}_{2}$ emission saved were also calculated.

Cristea, C. et al. [37] presented the economic evaluation of grid-connected civil solar photovoltaic systems in Romania under the new policy. The results showed that the PV systems were economically viable under subsidies, especially those with a smaller energy production capacity.

Ali, H., \& Khan, H. A. [38] simulated two 42kWp PV systems. The simulation results were compared with oneyear measured data of the PV systems installed at Lahore University of Management Science (LUMS), Lahore, Pakistan. The comparison results showed that Copper Indium Selenide (CIS) was a better choice from a performance ratio perspective because its annual energy output was higher than p-Si. However, p-Si had a better levelised cost of electricity, which made the technology a more viable commercial solution in Pakistan. 
Although the rooftop solar power has been paid a close attention to over all the world, it is still a new field in Vietnam [39]. Therefore, the results of this study will contribute to promoting solar energy exploitation and helping to reduce the amount of $\mathrm{CO}_{2}$ emitted and electricity costs for households in Vietnam.

The purposes of this article are:

- Designing, calculating and selecting solar panels, inverters and other equipment of the system according to the technical criteria for a household based on the actual load data;

- Using PVsyst software to simulate and evaluate the performance of the selected system;

- Using MS Excel software to calculate economic indicators based on the simulated data and different interest rate index scenarios to evaluate the economic viability of the project;

- Calculating the amount of $\mathrm{CO}_{2}$ emissions saved.

\section{The proposed grid-connected PV system}

\subsection{Components of On-grid PV system}

Based on the grid connection and its components, the rooftop solar power systems can be classified into on-grid systems, off-grid solar battery systems and hybrid rooftop solar battery systems [40]. The on-grid solar PV system is widely applied to households in Vietnam and its components are shown in the Figure 1 [41]. The system includes PV modules, inverters, wires, mounting system, electrical cabinets, protection components and two-way meters [42]. The PV module converts solar radiation into direct current (DC) which flows through the DC distribution box to the inverter. The inverter converts the direct current from the PV modules to the alternating current that powers the load and grid [43]. There are three main types of inverters: stand-alone inverters, gridconnected inverters [44] and battery backup inverters [45]. The stand-alone inverters supply power to electrical equipment in the system, but do not connect to the grid. The grid-connected inverters can connect to the grid and they are designed to automatically disconnect from the grid when there is a power cut, however, they do not provide backup power during the power cut. Battery backup inverters are a combination of the two previously mentioned types; they can supply the power to the system and they can also connect to the grid. The grid-connected inverters are widely used in rooftop solar power systems in Vietnam [41].

Under favourable weather conditions, the PV arrays absorb solar energy and generate electricity. Solar panels generate DC current that passes electricity through the DC connection boxes and then the inverters. During the daytime, depending on the household consumption and the solar PV system installed, the household consumption may be less or more than the electricity produced by the solar system at that time. When the PV system's electricity production exceeds the customer's demand, the excess energy of the system automatically passes through the bidirectional meter to the grid. In contrast, when the solar power system's electricity output is not enough to supply the household's demand, the shortage is taken from the grid. This connection is continuous and measured by a twoway meter. The excess energy from PV system is sold to the grid at a price of 8.38 cents $\mathrm{US} / \mathrm{kWh}$ (equivalent to $1,916 \mathrm{VND} / \mathrm{kWh}$ ) [12] while the electricity purchase price from the state power company is based on the retail electricity tariff [46].

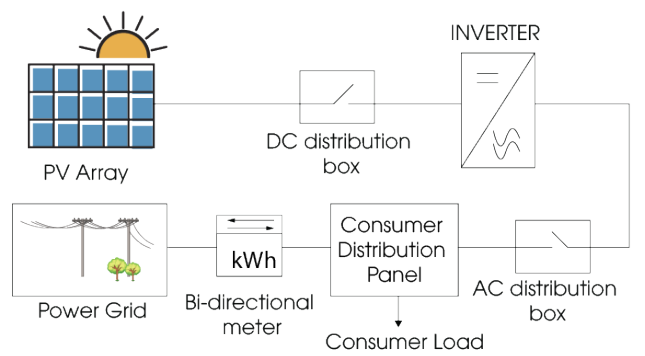

Figure 1. Diagram of the typical grid-connected PV system in Vietnam

\subsection{Design of the Grid-connected PV System for Household}

Designing a solar power system for a household must meet both technical and cost-optimal requirements. In particular, the selection of solar modules and inverters plays an important role in determining the initial investment cost and the quality of the system.

The most popular PV panel technologies can be divided into two main groups: crystalline technologies and thin film technologies. In which, crystal technology includes two main types: polycrystalline and monocrystalline [47]. In addition, the most common types of solar panels used are polycrystalline and monocrystalline $[48,49]$. Therefore, in this project, monocrystalline silicon solar panels are chosen because of their higher efficiency compared to polycrystalline silicon [50].

The solar modules are wired in series and connected to the inverter. The proposed design process is described in Figure 2 below. 


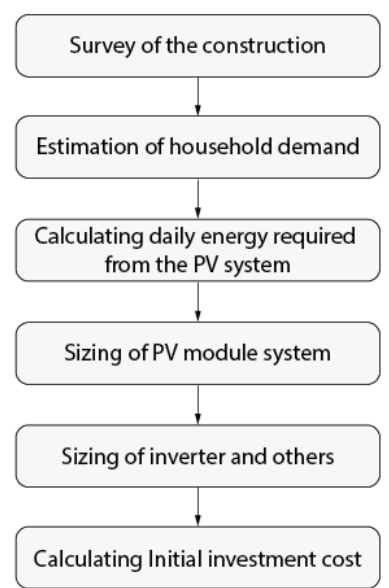

Figure 2. Procedures for Rooftop Solar System Design

\section{- Site information}

In this project, we design a rooftop solar system in Thu Dau Mot City, Vietnam at the latitude and longitude of $11^{\circ} 00^{\prime} 09^{\prime \prime}$ and $106^{\circ} 39^{\prime} 17^{\prime \prime}$, respectively (Figure 3 ). The direction of the house is north-south and the solar radiation coefficient on the horizontal plane in one year is 1804 $\mathrm{kWh} / \mathrm{m}^{2} /$ year $[9,10]$. Tilt angle of the roof is $38^{\circ}$.

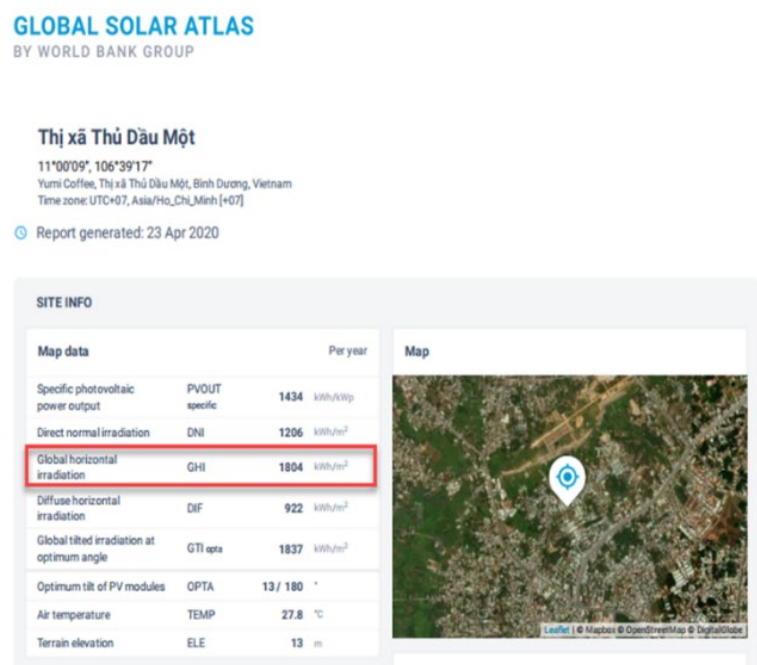

Figure 3. Site information and solar radiation [6].

- Estimation of household demand

The quantity of electrical equipment, power and estimated hours of use are presented as in Table 1 below. The total power of the appliances is $7,039 \mathrm{~W}$ and the estimated household energy consumption is $26,626 \mathrm{Wh}$ /day.

Table 1. Estimation of household's daily load profile.

\begin{tabular}{lllll}
\hline Appliances & $\begin{array}{l}\text { Power } \\
\text { (W) }\end{array}$ & Quantity & $\begin{array}{l}\text { Uses } \\
\text { (h/day) }\end{array}$ & $\begin{array}{l}\text { Energy } \\
\text { (Wh/day) }\end{array}$ \\
\hline
\end{tabular}

\begin{tabular}{lllll}
\hline $\begin{array}{l}\text { LED Light } \\
\text { Tube }\end{array}$ & 18 & 1 & 6 & 108 \\
$\begin{array}{l}\text { Decorative } \\
\text { Light }\end{array}$ & 12 & 4 & 3 & 144 \\
$\begin{array}{l}\text { LED } \\
\text { Recessed }\end{array}$ & 6 & 48 & 6 & 2,016 \\
$\begin{array}{l}\text { Light } \\
\text { Balcony }\end{array}$ & 12 & 6 & 2 & 144 \\
$\begin{array}{l}\text { LED Light } \\
\text { LED Square }\end{array}$ & 18 & 3 & 1 & 54 \\
$\begin{array}{l}\text { Light } \\
\text { Induction }\end{array}$ & 2,000 & 1 & 3 & 6,000 \\
$\begin{array}{l}\text { Cooking } \\
\text { Air- } \\
\text { conditioner }\end{array}$ & 1,125 & 2 & 3 & 6,750 \\
$\begin{array}{l}\text { Computer } \\
\text { Electrical }\end{array}$ & 150 & 3 & 5 & 2,250 \\
Cooker & 800 & 1 & 2 & 1,600 \\
Fan & 55 & 4 & 5 & 1,100 \\
$\begin{array}{l}\text { Ventilator } \\
\text { Fan }\end{array}$ & 25 & 1 & 0.5 & 25 \\
TV & 117 & 3 & 5 & 1,755 \\
$\begin{array}{l}\text { Fridge } \\
\text { Total }\end{array}$ & 195 & 1 & 24 & 4,680 \\
\hline & $7,039 \mathrm{~W}$ & & & 26,626 \\
\hline
\end{tabular}

- Calculating daily energy required from the PV system

The energy that needs to be produced by solar arrays is [42]:

$$
E_{P V, \text { required }}=1.3 \times E_{\text {Load }}=1.3 \times 26626=34613.8 \quad(\mathrm{Wp} / \text { day })
$$

Where, $\mathrm{E}_{\mathrm{PV} \text {,required }}$ is the total amount of energy that the solar system needs to produce in a day; $E_{\text {Load: daily }}$ energy consumption of the household.

The required power of the PV system is

$$
P_{P V, \text { required }}=\frac{E_{P V, \text { required }}}{C_{r}}=\frac{34613.8}{4.94}=7000.8(\mathrm{Wp})
$$

Where, $\mathrm{P}_{\mathrm{PV}}$, required: Power of $\mathrm{PV}$ system needs to be installed (Wp); $E_{P V}$, required: The total amount of energy that the solar system needs to produce in a day (Wh/day); $\mathrm{C}_{\mathrm{r}}$ : Solar radiation capacity $\left(\mathrm{kWh} / \mathrm{m}^{2} /\right.$ day $)$.

In this study, the possibility of future load expansion is also considered, so the required system power to be chosen is $8 \mathrm{kWp}$.

Panels with a power of $380 \mathrm{Wp}$ are selected, then the number of panels to be installed is:

$$
N_{\text {panel, required }}=\frac{P_{P V, \text { required }}}{P_{\text {panel, }, \text { rate }}}=\frac{8000}{380}=21.05
$$

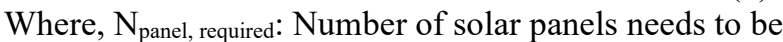
installed; $\mathrm{P}_{\mathrm{PV}}$, required: Power of PV system needs to be installed (Wp); $\mathrm{P}_{\text {panel, rate: }}$ Rated power of solar panel (Wp).

In this project, the selected number of modules is 22 and their type is LX-380M/156-72.

- Sizing of inverter

The power of the inverter is selected according to the rule $[42,51]$ : 
$\mathrm{P}_{\text {inv }} \geqslant 125 \% \mathrm{x} \mathrm{P}_{\text {Load }}=125 \% \mathrm{x} 7039=8798.75(\mathrm{Wp})$

Where, $\mathrm{P}_{\text {inv }}$ : the rated power of the inverter, $\mathrm{P}_{\text {Load }}$ the household's demand.

In this project, the power of the inverters selected is $10 \mathrm{kWp}$. Two inverters will be installed; and the power of each inverter is $5 \mathrm{kWp}$.

Number of modules per string:

$\mathrm{N}_{\max }=\mathrm{V}_{\text {MPPT }} / \mathrm{V}_{\text {MPP }}=480 / 39.8=12.1$

Where, $\mathrm{N}_{\max }$ : Number of modules per string; $\mathrm{V}_{\text {MPPT: }}$ Maximum input MPPT DC voltage of the Inverter given by the manufacturer (V); $\mathrm{V}_{\mathrm{MPP}}$ : Maximum DC Voltage of PV Module (V).

In this project, 22 solar modules are equally divided into two strings, each connected to one inverter. The singleline diagram of the PV system is described in Figure 4. The $3 \mathrm{D}$ model of the house after being installed with the panels is shown in Figure 5. Table 2 describes the main parameters of equipment used in the household solar PV system.

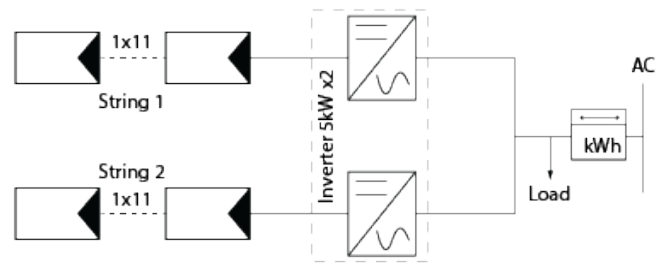

Figure 4. The single line diagram of the gridconnected PV system

Table 2. Main equipment of the grid connected PV system.

\begin{tabular}{ll}
\hline Parameters & Specification \\
\hline PV module & LX - 380M/156 -72+ \\
Model & $\begin{array}{l}\text { Luxor } \\
\text { Monocrystalline } \\
\text { Manufacturer }\end{array}$ \\
Types of PV cells & 72 \\
Number of cells & $380 \mathrm{Wp}$ \\
Rated Power (Pmax) & $39.8 \mathrm{~V}$ \\
Voltage at maximum power & \\
(VMPP) & $9.58 \mathrm{~A}$ \\
Current at maximum power & \\
(IMPP) & $10.05 \mathrm{~A}$ \\
Short-circuit current (Isc) & $47.5 \mathrm{~V}$ \\
Open-circuit voltage (Uoc) & $19.6 \%$ \\
Efficiency at STC/ module area & $21.7 \%$ \\
Efficiency at STC/ cells area & $-0.39 \%{ }^{\circ} \mathrm{C}$ \\
Temperature Coefficient of P $\mathrm{max}$ & 22 \\
No. of modules & $1956 \times 992$ \\
Module dimensions (mm) (LxW) & $38.5 \mathrm{~m} 2$ \\
Total cell area & $42.7 \mathrm{~m}{ }^{2}$ \\
Total module area & $45 \mathrm{~m} 2$ \\
Space requirement for system \\
installation
\end{tabular}

\begin{tabular}{ll}
\hline Rated output power & $5 \mathrm{~kW}$ \\
Max. efficiency & $98.58 \%$ \\
Max. input voltage & $600 \mathrm{~V}$ \\
$\begin{array}{l}\text { Full power MPPT voltage range } \\
\text { (VMPPT) }\end{array}$ & $260-480 \mathrm{~V}$ \\
Max. input current per MPPT & $11 \mathrm{~A}$ \\
(IMPPT) & \\
No. of inverters & 2 \\
Net weight & $10.6 \mathrm{~kg}$ \\
Dimensions $(\mathrm{mm})(\mathrm{LxW} \times \mathrm{H})$ & $375 \times 375 \times 161.5$ \\
\hline
\end{tabular}

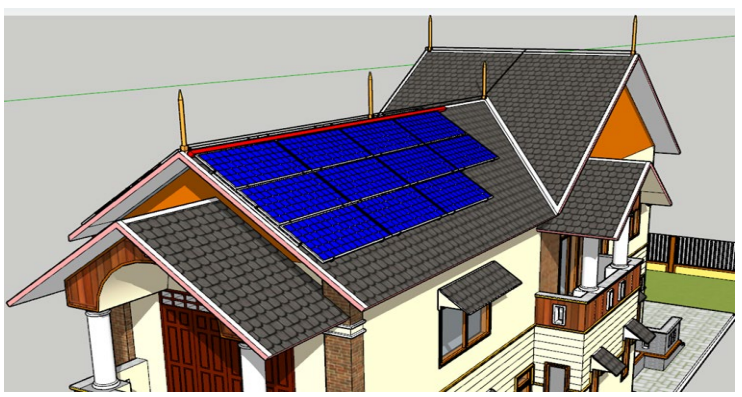

Figure 5. 3D house model in Sketchup software

\subsection{Initial investment cost}

Based on the current prices of equipment and services, the total initial investment cost is calculated as below:

Table 3. Initial investment for the rooftop solar PV system.

\begin{tabular}{llll}
\hline Items & Quantity & $\begin{array}{l}\text { Prices } \\
\text { (VND) }\end{array}$ & $\begin{array}{l}\text { Costs } \\
\text { (VND) }\end{array}$ \\
\hline $\begin{array}{l}\text { Solar Panel } \\
(380 W p)\end{array}$ & 22 & $3,040,000$ & $66,880,000$ \\
$\begin{array}{l}\text { Inverter 5kWp } \\
\begin{array}{l}\text { Cabling, } \\
\text { installation } \\
\text { cost, and } \\
\text { others }\end{array}\end{array}$ & 2 & $12,500,000$ & $25,000,000$ \\
$\begin{array}{l}\text { Total Initial } \\
\text { Cost }\end{array}$ & & $40,566,707$ \\
\hline
\end{tabular}

\section{Simulation}

Simulating a rooftop solar power system requires input parameters such as solar radiation intensity, local weather conditions, building direction and other technical factors. In this study, PVsyst 6.7.0 software [13] is used to simulate the system because of its reliability $[19,24,52]$.

\subsection{Performance parameters}

Solar PV system efficiency evaluation is carried out according to the guidance of IEC 61724 standard [53]. It is described as follows:

- Array Yield ( $\left.\mathrm{Y}_{\mathrm{a}}\right)$ 


$$
Y_{a}=\frac{E_{D C}}{P_{P V, \text { rate }}}
$$

Where, $\mathrm{Y}_{\mathrm{a}}$ (array yield): the ratio of PV array power output to its rated power $\left[\mathrm{kWh} / \mathrm{kWp} /\right.$ day]; $\mathrm{E}_{\mathrm{DC}}$ : daily $\mathrm{DC}$ energy output from solar arrays $\left(\mathrm{kWh} /\right.$ day); $\mathrm{P}_{\mathrm{PV}}$, rate: the rated output power of the PV array $(\mathrm{kWp})$.

- System Yield $\left(\mathrm{Y}_{\mathrm{f}}\right)$

$Y_{f}=\frac{E_{A C}}{P_{P V, \text { rate }}}$

Where, $\mathrm{Y}_{\mathrm{f}}$ (system yield): the ratio between the total AC energy obtained from the inverter's output and the rated power of the solar PV arrays $\left[\mathrm{kWh} / \mathrm{kWp} /\right.$ day]; $\mathrm{E}_{\mathrm{AC}}$ : the total $\mathrm{AC}$ energy of the inverter generated by the PV power system for a specific time ( $\mathrm{kWh})$.

- Reference System Yield $\left(\mathrm{Y}_{\mathrm{r}}\right)$

$Y_{r}=\frac{S_{r}}{G_{o}}$

Where, $\mathrm{Y}_{\mathrm{r}}$ (reference system yield): the ideal array yield according to array nominal installed power at standard condition as defined by manufacturer, without any loss; $\mathrm{Y}_{\mathrm{r}}$ : numerically equal to the incident energy in the array plane, expressed in $\left[\mathrm{kWh} / \mathrm{m}^{2} / \mathrm{day}\right] ; \mathrm{S}_{\mathrm{r}}$ : the total horizontal radiation on the panel $\left(\mathrm{kW} / \mathrm{m}^{2}\right) ; \mathrm{G}_{\mathrm{o}}$ : the global radiation at standard test conditions $\left(1 \mathrm{~kW} / \mathrm{m}^{2}\right)$.

- Performance Ratio (PR)

$P R=\frac{Y_{f}}{Y_{r}}$

Where, performance ratio (PR) of the whole system is related to the finally output power of the PV system and the nominal installed PV power.

- Collection Loss (Lc)

$\mathrm{L}_{\mathrm{C}}$ is the loss of PV arrays. It is calculated by:

$L_{c}=Y_{r}-Y_{a}$

\section{- System Loss (Ls)}

$\mathrm{L}_{\mathrm{s}}$ is the inverter loss in the PV system. It is calculated by:

$$
L_{s}=Y_{a}-Y_{f}
$$

\subsection{Simulation by PVSYST Software}

The simulation process using PVSYST software with Meteonorm 7.1 built-in weather data $[23,29,54]$ is described in Figure 6.

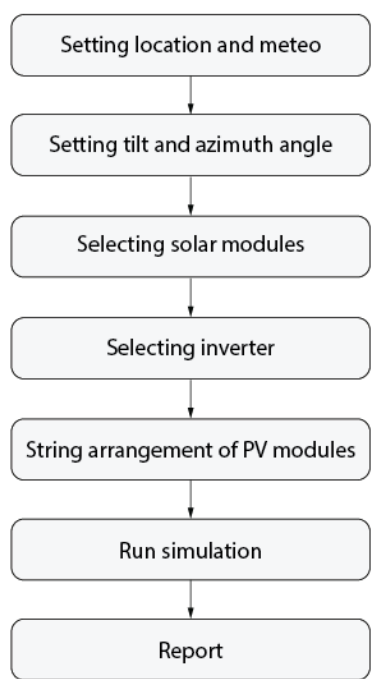

Figure 6. Simulation process by PVsyst software

\subsection{Results of Simulation and Discussion}

The simulation results show that the total energy generated is $11.106 \mathrm{MWh} /$ year, the monthly production is shown in Table 4 and the annual average performance ratio (PR) which shown in Figure 7 is $81.7 \%$.

Table 4. The weather of the proposed location and

\begin{tabular}{|c|c|c|c|c|c|c|c|c|}
\hline & $\begin{array}{l}\text { GlobHor } \\
\mathrm{kWh} / \mathrm{m}^{2}\end{array}$ & $\begin{array}{l}\text { DiffHor } \\
\mathrm{kWh} / \mathrm{m}^{2}\end{array}$ & $\begin{array}{c}\text { TAmb } \\
{ }^{\circ} \mathrm{C}\end{array}$ & 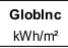 & $\begin{array}{l}\text { Globeff } \\
\mathrm{kWh} / \mathrm{m}^{2}\end{array}$ & $\begin{array}{c}\text { EArray } \\
\text { MWh }\end{array}$ & $\begin{array}{l}\text { E_Grid } \\
\text { MWh }\end{array}$ & PR \\
\hline January & 153.7 & 70.82 & 26.33 & 136.8 & 132.1 & 0.968 & 0.936 & 0.818 \\
\hline February & 147.9 & 69.96 & 27.11 & 131.4 & 127.3 & 0.922 & 0.891 & 0.812 \\
\hline March & 169.7 & 82.87 & 28.40 & 152.3 & 148.0 & 1.063 & 1.027 & 0.807 \\
\hline April & 152.0 & 82.57 & 29.04 & 136.2 & 132.1 & 0.954 & 0.921 & 0.809 \\
\hline May & 163.9 & 90.72 & 28.50 & 146.2 & 141.7 & 1.029 & 0.994 & 0.813 \\
\hline June & 155.1 & 80.91 & 27.50 & 138.0 & 133.7 & 0.975 & 0.942 & 0.817 \\
\hline July & 163.5 & 90.47 & 27.34 & 145.7 & 141.1 & 1.033 & 0.999 & 0.820 \\
\hline August & 161.5 & 86.98 & 27.29 & 144.9 & 140.5 & 1.027 & 0.992 & 0.819 \\
\hline September & 135.4 & 82.64 & 26.67 & 120.2 & 116.4 & 0.856 & 0.826 & 0.822 \\
\hline October & 143.9 & 81.42 & 26.75 & 128.6 & 124.4 & 0.915 & 0.883 & 0.821 \\
\hline November & 134.5 & 74.67 & 26.35 & 120.6 & 116.4 & 0.861 & 0.831 & 0.824 \\
\hline December & 141.4 & 64.38 & 26.21 & 126.2 & 121.8 & 0.895 & 0.864 & 0.819 \\
\hline \begin{tabular}{|l|} 
Year \\
\end{tabular} & 1822.5 & 958.41 & 27.29 & 1627.0 & 1575.5 & 11.498 & 11.106 & 0.817 \\
\hline
\end{tabular}
monthly energy production
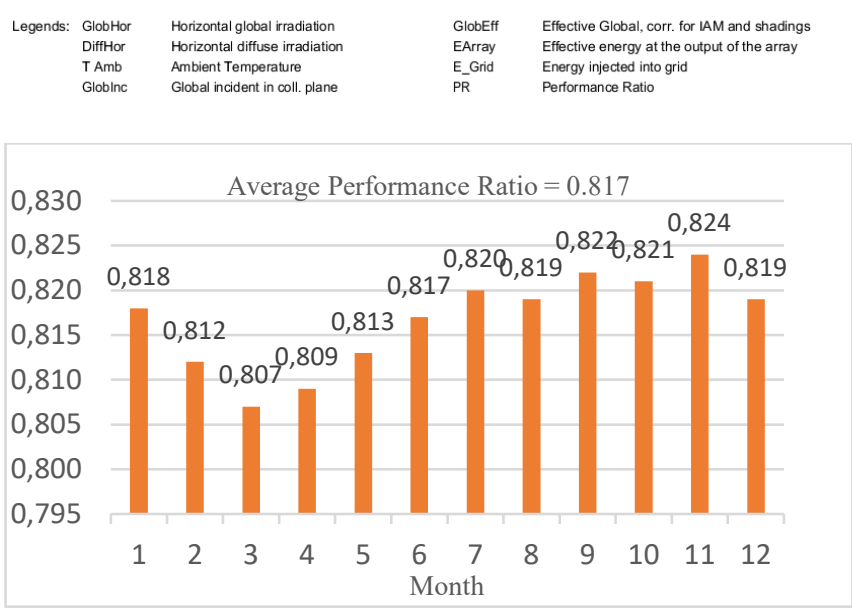

Figure 7. Graph of monthly performance ratio of the grid PV system

Figure 8 shows a diagram of the losses of the rooftop solar power system. The results show that the loss of heat and global incident irradiation are high $(10.6 \%$ and $10.7 \%$ respectively). The heat loss is high because Thu Dau Mot 
City is located in the South of Vietnam where the temperature is high compared to the standard conditions. In addition, the loss of global incident irradiation is aslo high since the tilt angle of the panel is steeper than the optimal angle $\left(13^{\circ}-16^{\circ}\right)[7]$. However, the other losses are quite small, ranging from $0.1 \%$ to $3.3 \%$.

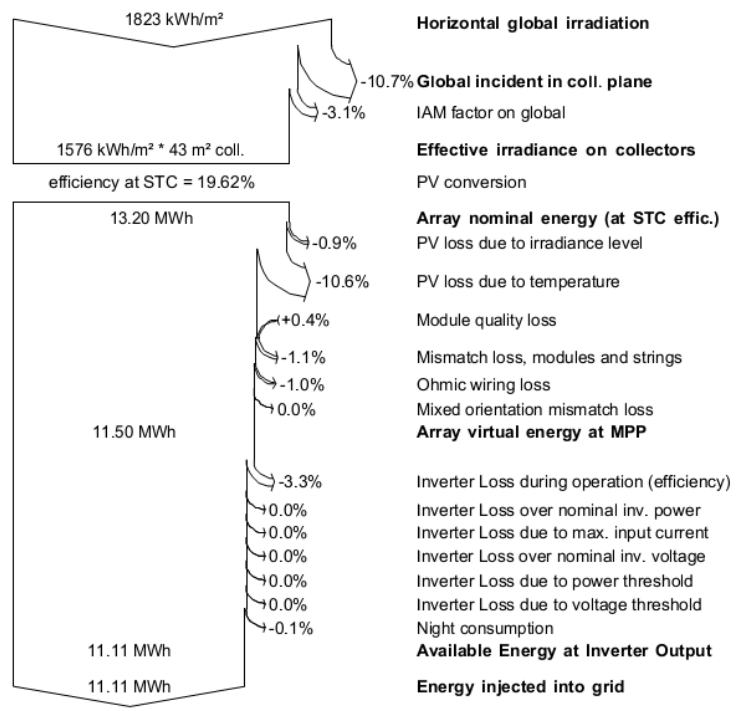

Figure 8. Loss diagram of the grid-connected PV system

Figure 9 shows the types of losses in $\mathrm{kWp}$ of the system power output, in which the PV array loss is 0.69 $\mathrm{kWh} / \mathrm{kWp} /$ day and the inverter loss is $0.13 \mathrm{kWh} / \mathrm{kWp} /$ day. The amount of electricity produced by the system is 3.64 $\mathrm{kWh} / \mathrm{kWp} /$ day. There is not much difference in the power generated in different months of the year. The electricity generated from March to August is slightly higher than the remains, because it is the dry season.

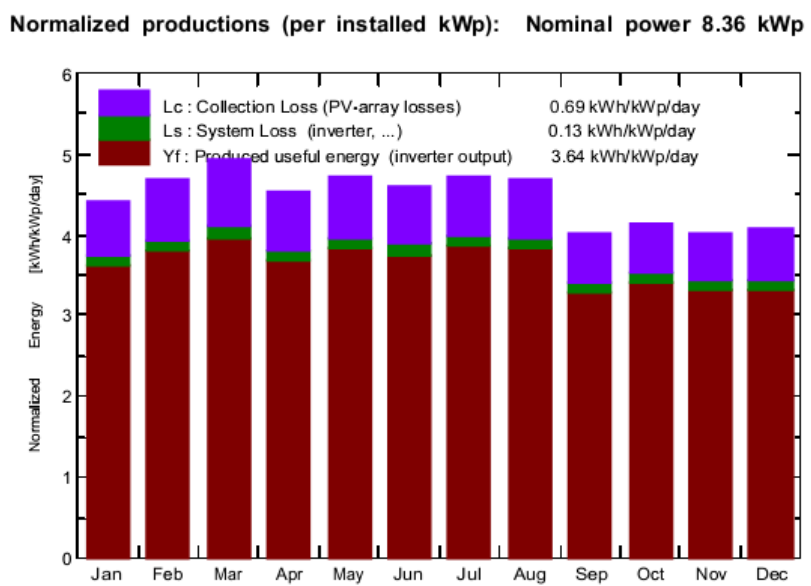

Figure 9. Normalized power production and loss factors

\section{Economic and Environmental Impact Analysis}

\subsection{Economic Indicators}

Based on the simulation results and the total cost of installing the system, the authors analyse the economic indicators of the project, including net present value (NPV), benefit cost ratio (BCR), internal rate of return (IRR), payback period (PB) and levelised cost of energy (LCOE) [55-59]. The lifetime of the PV system is estimated to be 20 years, and 10 years for the inverter.

Table 5. Electricity tariffs of urban areas in Vietnam [46]

\begin{tabular}{ll}
\hline Segment Tariff & Price per unit (VND/kWh) \\
\hline $0-50 \mathrm{kWh}$ & 1,678 \\
$51-100 \mathrm{kWh}$ & 1,734 \\
$101-200 \mathrm{kWh}$ & 2,014 \\
$201-300 \mathrm{kWh}$ & 2,536 \\
$301-400 \mathrm{kWh}$ & 2,834 \\
Above $401 \mathrm{kWh}$ & 2,927 \\
\hline
\end{tabular}

The profit generated by the solar PV system is equal to the amount of electricity sold to the utility company plus the amount of electricity consumed on a daily basis.

According to the tiered electricity tariff, when a solar energy system is adopted, the household does not have to pay for electricity at the rate of $2,834 \mathrm{VND} / \mathrm{kWh}$ (applied for the consumed electricity amount from 301 to $400 \mathrm{kWh}$ per month), shown in Table 5. Therefore, the monthly savings is calculated by multiplying the consumed electricity amount by $2,834 \mathrm{VND}$. The buying price of solar power by the power company is $1,916 \mathrm{VND} / \mathrm{kWh}$. Assuming that household energy consumption between daytime and night-time is equal. Such assumption is based on the actual survey and shown in Table 6.

Assuming that the load and electricity price are constant during the life of the project, and the performance degradation of the panel is $1 \%$ per year. Then, the annual profit is calculated in Table 6 and Table 7. 
Table 6. Energy consumption and profitability of the rooftop solar PV system

\begin{tabular}{|c|c|c|c|c|c|}
\hline \multirow[t]{2}{*}{ Month } & \multicolumn{2}{|c|}{$\begin{array}{r}\text { Household } \\
\text { Energy } \\
\text { Oonsumption } \\
(\mathrm{kWh})\end{array}$} & $\begin{array}{r}\text { Energy } \\
\text { by } \\
\text { PVsyst } \\
(\mathrm{kWh})\end{array}$ & $\begin{array}{r}\text { Unused } \\
\text { Energy } \\
(\mathrm{kWh})\end{array}$ & $\begin{array}{l}\text { Revenue of } \\
\text { PV System } \\
\text { (VND) }\end{array}$ \\
\hline & $\begin{array}{r}\text { Day } \\
(1)\end{array}$ & $\begin{array}{r}\text { Night } \\
\text { (2) }\end{array}$ & (3) & $(3-1)$ & $(Z)$ \\
\hline 1 & 221.45 & 221.45 & 936.00 & 714.55 & 1996667.10 \\
\hline 2 & 240.85 & 240.85 & 891.00 & 650.15 & 1928 \\
\hline 3 & 247.70 & 247.70 & 1027.00 & 779.30 & 0.60 \\
\hline 4 & 236.25 & 236.25 & 921.00 & 684.75 & 3.50 \\
\hline 5 & 217.85 & 217.85 & 994.00 & 776.15 & 0.30 \\
\hline 6 & 261.45 & 261.45 & 942.00 & 680.55 & 2044883.10 \\
\hline 7 & 236.25 & 236.25 & 999 & 762 & 1.50 \\
\hline 8 & 197.25 & 197.25 & 992.00 & .75 & 17.50 \\
\hline 9 & 256.85 & 256.85 & 826.00 & 569.15 & \\
\hline 10 & 201.85 & 201.85 & 883.00 & 681.15 & 1877126.30 \\
\hline 11 & 270.65 & 270.65 & 831.00 & 560.35 & 1840652.70 \\
\hline 12 & 275.2 & 275.2 & 864.00 & 588.80 & 57.60 \\
\hline $\begin{array}{l}\text { Total: } \\
\text { Where, }\end{array}$ & 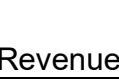 & 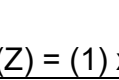 & 334 & 1 & 23907880.80 \\
\hline
\end{tabular}

Table 7. Cumulative cash flow at discount rate of $11 \%$

\begin{tabular}{rrrrr}
$\begin{array}{r}\text { End } \\
\text { of } \\
\text { Year }\end{array}$ & $\begin{array}{r}\text { Total } \\
\text { Cost }\end{array}$ & $\begin{array}{r}\text { Revenue } \\
\text { of PV } \\
\text { System }\end{array}$ & $\begin{array}{r}\text { Net } \\
\text { Cash } \\
\text { Flow }\end{array}$ & $\begin{array}{r}\text { Cumulative } \\
\text { Cash } \\
\text { Flow }\end{array}$ \\
& & & & \\
& $(1000$ & $(1000$ & $(1000$ & $(1000$ \\
VND $)$ & VND) & VND $)$ & VND $)$ \\
\hline 0 & 132446.7 & & 132446.7 & $-132,446.7$ \\
1 & 1324.5 & 23907.9 & 22583.4 & $-112,101.3$ \\
2 & 1324.5 & 23695.1 & 22370.6 & $-93,944.8$ \\
3 & 1324.5 & 23484.4 & 22160.0 & $-77,741.6$ \\
4 & 1324.5 & 23275.9 & 21951.4 & $-63,281.5$ \\
5 & 1324.5 & 23069.4 & 21744.9 & $-50,377.0$ \\
6 & 1324.5 & 22865.0 & 21540.5 & $-38,860.5$ \\
7 & 1324.5 & 22662.6 & 21338.2 & $-28,582.8$ \\
8 & 1324.5 & 22462.3 & 21137.8 & $-19,410.6$ \\
9 & 1324.5 & 22264.0 & 20939.5 & $-11,224.8$ \\
$10\left(^{*}\right)$ & 26324.5 & 22067.6 & -4256.9 & $-12,724.0$ \\
11 & 1324.5 & 21873.2 & 20548.8 & $-6,204.2$ \\
12 & 1324.5 & 21680.8 & 20356.3 & -385.6 \\
13 & 1324.5 & 21490.3 & 20165.8 & $4,807.4$ \\
14 & 1324.5 & 21301.6 & 19977.2 & $9,442.0$ \\
15 & 1324.5 & 21114.9 & 19790.4 & $13,578.3$ \\
16 & 1324.5 & 20930.0 & 19605.6 & $17,269.9$ \\
17 & 1324.5 & 20747.0 & 19422.6 & $20,564.6$ \\
18 & 1324.5 & 20565.9 & 19241.4 & $23,505.1$ \\
19 & 1324.5 & 20386.5 & 19062.0 & $26,129.5$ \\
20 & 1324.5 & 20208.9 & 18884.4 & $28,471.8$ \\
\hline
\end{tabular}

(*): Inverter Replacement

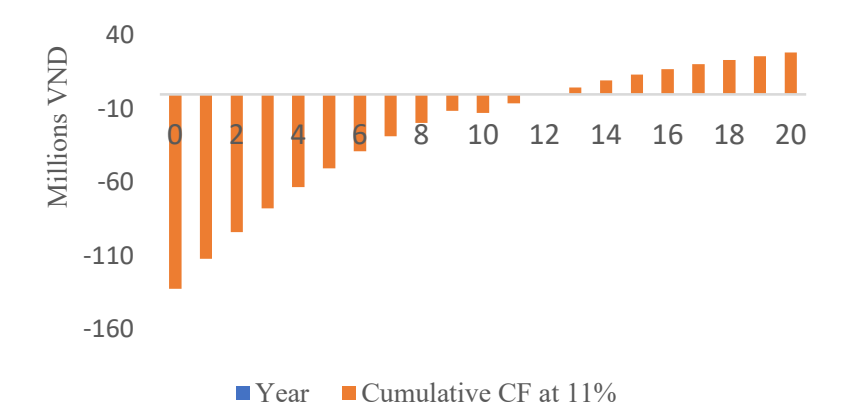

Figure 10. Cumulative Cash Flow at discount rate of $11 \%$

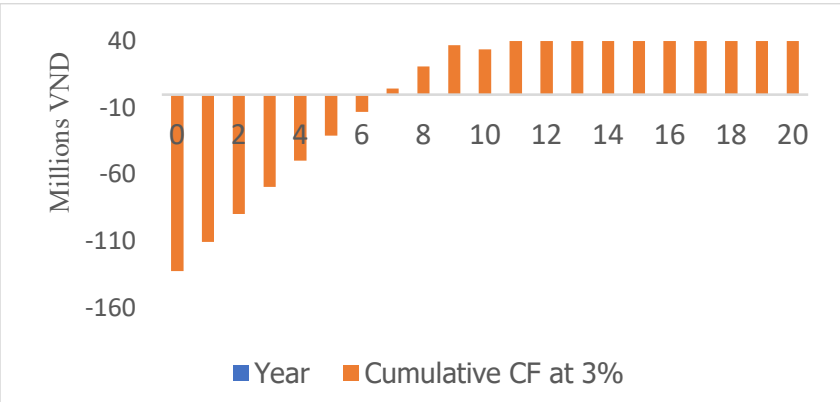

Figure 11. Cumulative Cash Flow at discount rate of $3 \%$

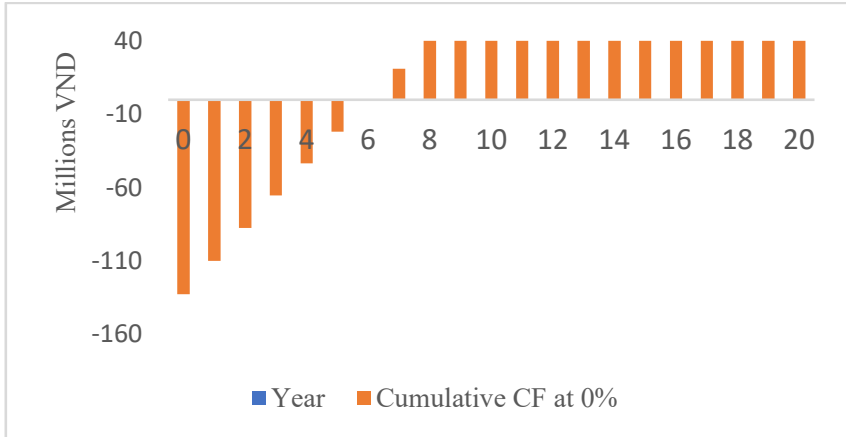

Figure 12. Cumulative Cash Flow at discount rate of $0 \%$

NPV is the net present value, which is the difference of the present value of the cash inflow minus the present value of the cash outflow [57]. The project is effective if NVP > 0 . The calculated result is shown in Table 7. The formula for calculating the NPV is:

$N P V=\sum_{n=0}^{N} \frac{B_{n}}{(1+i)^{n}}-\sum_{n=0}^{N} \frac{C_{n}}{(1+i)^{n}}$

Where, $B_{n}$ : expected benefit at the end of the year $n ; C_{n}$ : expected cost at the end of year $n$; $r$ : discount rate; N: total lifetime of the system; $n$ : the $\mathrm{n}^{\text {th }}$ year.

IRR is the internal rate of return which means the rate of return for the project itself. If the IRR value is greater than the expected interest rate, then the project is assessed as feasible [57]. IRR is the solution of the equation NPV = 0 where $\mathrm{i}=\mathrm{IRR}$, the calculated results are shown in Table 8 . 
$\sum_{n=0}^{N} \frac{B_{n}}{(1+i)^{n}}-\sum_{n=0}^{N} \frac{C_{n}}{(1+i)^{n}}=0$

Benefit cost ratio (BCR) is the ratio of the total present value benefit over the total present value cost given by equation (14), the BCR value greater than one indicates a profitable PV project [58].

$B C R=\frac{\sum_{n=0}^{N} \frac{B_{n}}{(1+i)^{n}}}{\sum_{n=0}^{N} \frac{C_{n}}{(1+i)^{n}}}$

Payback period (PB) determines how long it takes for a project to reach break-even point. The shorter the payback period is, the better it is [58].

$\sum_{n=0}^{N}\left(B_{n}-C_{n}\right)=0$

Levelised cost of electricity (LCOE) $[57,58]$ is the marginal cost of electricity production, used to compare costs from different sources. LCOE is calculated in the following formula (16).

$L C O E=\frac{\text { Lifecycle cost }}{\text { Lifetime energy production }}=\frac{\text { Initial } \operatorname{Cos} t+\sum_{n=1}^{N} \frac{C_{n}}{(1+r)^{n}}}{\sum_{n=1}^{N} \frac{E_{n}}{(1+r)^{n}}}$

Where, $E_{n}$ is the $n^{\text {th }}$ year energy produced by the PV system.

Table 8. Economic indicators

\begin{tabular}{|r|r|r|r|}
\hline $\begin{array}{r}\text { Economic } \\
\text { evaluation } \\
\text { criteria }\end{array}$ & $\begin{array}{r}\text { Discount } \\
\text { rate } \\
\text { at } 0 \%\end{array}$ & $\begin{array}{r}\text { Discount } \\
\text { rate } \\
\text { at } 3 \%\end{array}$ & $\begin{array}{r}\text { Discount } \\
\text { rate } \\
\text { at } 11 \%\end{array}$ \\
\hline $\begin{array}{r}\text { Payback } \\
\text { Period } \\
\text { (years) }\end{array}$ & 6.0045 & 6.7409 & 12.0742 \\
\hline NPV (VND) & $256,117,22$ & $159,424,54$ & $28,471,809$ \\
& 3.18 & 5.93 & .08 \\
\hline IRR (\%) & 14.40 & 14.40 & 14.40 \\
\hline BCR & 2.11 & 1.71 & 1.03 \\
\hline LCOE & 909.53 & 1124.01 & 1825.36 \\
\hline VND/kWh) & \multicolumn{3}{|c}{20 years } \\
\hline Project life & & & \\
\hline
\end{tabular}

The calculation results of economic indicators are described in Table 8 , corresponding to 3 cases where the discount coefficient is $0 \%, 3 \%$ and $11 \%$, respectively.

In the case of discount rate of $0 \%$, both the expected interest rate (estimated to be $8 \%$ ) and inflation (estimated to be $3 \%$ ) are not considered. In the case of discount rate of $3 \%$, only the inflation coefficient is considered while the expected interest rate is not considered. In the case of discount rate of $11 \%$, both the expected interest rate and the inflation rate are taken into account.

According to the calculated results, the IRR is greater than the discount coefficient $(14.40 \%>11 \%)$ and NPV $>$ 0 ; payback period is 12.0742 years, 6.7409 years and
6.0045 years corresponding to discount rates of $11 \%, 3 \%$ and $0 \%$, respectively; $\mathrm{BCR}$ is $1.03,1.71$ and 2.11 corresponding to discount rates of $11 \%, 3 \%$ and $0 \%$, respectively.

Figure 10 to 12 show the cumulative cash flow at discount rate of $11 \%, 3 \%$ and $0 \%$, respectively.

\subsection{Environmental Impact}

The rooftop solar project not only brings economic benefits and contributes to solving the problem of electricity shortages, but also contributes to reducing $\mathrm{CO}_{2}$ emissions to the environment.

The amount of $\mathrm{CO}_{2}$ emission reduction of the project in 20 years is 174.9 tons, calculated by the following formula (17).

$t_{\mathrm{CO}_{2}}=\sum_{n=1}^{N} E_{\text {Grid }_{n}} x E F_{\text {Grid }}$

Where, $E_{\text {Gridn }}$ : the energy produced by the system in $n^{\text {th }}$ year; $\mathrm{EF}_{\mathrm{Grid}}$ (the $\mathrm{CO}_{2}$ emission factor of the Vietnamese grid) $=0.8649 \mathrm{t}_{\mathrm{CO} 2} / \mathrm{MWh}[41]$.

\section{Conclusion}

Although the rooftop solar power system has thrived in Vietnam in recent years, few studies on economic and technical evaluation for residential rooftop solar power projects have been in place so far. Therefore, in this article, the authors tried to present the detailed information on designing, simulating and economically evaluating the $8.36 \mathrm{kWp}$ rooftop solar power project at a specific household of Vietnam. The findings are summarized below:

- The main details of the installation of the solar power system have been clearly reviewed and explained.

- The annual energy generated is $11,106 \mathrm{kWh}$; the amount of $\mathrm{CO}_{2}$ saved is 174.9 tons/20 years and annual average system efficiency is $81.17 \%$.

- The $8.36 \mathrm{kWp}$ rooftop solar power system requires an initial investment of $132,446,707$ VND (equivalent to 5,691.7 USD) while the annual profit from selling electricity to the power company is $23,907,880.8 \mathrm{VND}$ (equivalent to 1,027.4 USD).

- The economic analysis of the system indicates that the project is economically feasible at the discount rate of $11 \%$, the payback period of 12.0742 years; BCR of 1.03; LCOE of 1825.36 $\mathrm{VND} / \mathrm{kWh} ; \mathrm{IRR}=14 \%$ and $\mathrm{NPV}>0$.

In conclusion, the above economic and technical analyses showed that the rooftop solar PV system is profitable for households, helps to reduce environmental 
pollution and contributes to the implementation of green economy development in Vietnam in the context of rapidly increasing global climate change. However, two economic weaknesses should be noted. If both the bank interest rate and the inflation rate are taken into account, the BCR is low and the project's payback period is long. Nevertheless, it is clear that there is an advantage of developing a household rooftop solar PV system, that is, the price of solar panels and inverters is reducing, making solar power projects more economical.

It is expected that this study will help stakeholders in the Vietnamese market understand the viability of residential rooftop solar PV installations.

\section{Conflict of Interest}

The author declares no conflict of interest.

\section{Acknowledgment}

The authors would like to acknowledge Thu Dau Mot University in Vietnam for its support. This research is funded by Thu Dau Mot University under grant number ĐT.20-027.

\section{References}

[1] Sayed, E. T., Wilberforce, T., Elsaid, K., Rabaia, M. K. H., Abdelkareem, M. A., Chae, K. J., \& Olabi, A. G. (2020). A critical review on Environmental Impacts of Renewable Energy Systems and Mitigation Strategies: Wind, Hydro, Biomass and Geothermal. Science of The Total Environment, 144505. https://doi.org/10.1016/j.scitotenv.2020.144505

[2] Nong, D., Wang, C., \& Al-Amin, A. Q. (2020). A critical review of energy resources, policies and scientific studies towards a cleaner and more sustainable economy in Vietnam. Renewable and Sustainable Energy Reviews, 134, 110117. https://doi.org/10.1016/i.rser.2020.110117

[3] Ti, Z., Deng, X. W., \& Yang, H. (2020). Wake modeling of wind turbines using machine learning. Applied Energy, 257, 114025. https://doi.org/10.1016/j.apenergy.2019.114025

[4] Sheng, W. (2019). Wave energy conversion and hydrodynamics modelling technologies: A review. Renewable and Sustainable Energy Reviews, 109, 482-498. https://doi.org/10.1016/j.rser.2019.04.030

[5] Hnatov, A., Arhun, S., Dziubenko, O., \& Ponikarovska, S. (2018). Choice of electric engines connection circuits in electric machine unit of electric power generation device. Majlesi Journal of Electrical Engineering, 12(4), 85-93.

[6] Patlins, A., Hnatov, A., Arhun, S., \& Dzyubenko, O. (2019). Design and research of constructive features of paving slabs for power generation by pedestrians. Transportation Research Procedia, 40, 434-441. https://doi.org/10.1016/j.trpro.2019.07.063

[7] Zhang, Y., Ren, J., Pu, Y., \& Wang, P. (2020). Solar energy potential assessment: A framework to integrate geographic, technological, and economic indices for a potential analysis. Renewable Energy, 149, 577-586. https://doi.org/10.1016/j.renene.2019.12.071
[8] Hoi, H. T. (2020). Potential for Solar Energy Development in Vietnam. International Journal of Environmental Science and Development, 11(7). http://dx.doi.org/10.18178/ijesd.2020.11.7.1276

[9] The World Bank. Global Solar Atlas version 2.0 (on 23-Oct2019) https://globalsolaratlas.info/download/vietnam

[10] Polo, J., Bernardos, A., Navarro, A. A., FernandezPeruchena, C. M., Ramírez, L., Guisado, M. V., \& Martínez, S. (2015). Solar resources and power potential mapping in Vietnam using satellite-derived and GIS-based information. Energy Conversion and Management, 98, 348-358. https://doi.org/10.1016/j.enconman.2015.04.016

[11] PM Decision 2068/QĐ-TTg on Renewable Energy Development Strategy to 2030 outlook 2050.

[12] PM Decision 13/2020/QĐ-TTg on Mechanisms to Promote the Development of Solar Power Projects in Viet Nam.

[13] PVsyst Software https://www.pvsyst.com/

[14] Solar Pro Software https://www.lapsys.co.jp

[15] Sunny Design Software https://www.sunnydesignweb.com/

[16] PVSOL Software https://valentin-software.com/en/

[17] Kyprianou, S. K., Christofides, N. G., Papadakis, A. P., \& Polycarpou, A. (2010). Feasibility study of a $150 \mathrm{kWp}$ Photovoltaic park in Cyprus. https://doi.org/10.1049/cp.2010.0911

[18] Karki, P., Adhikary, B., \& Sherpa, K. (2012, September). Comparative study of grid-tied photovoltaic (PV) system in Kathmandu and Berlin using PVsyst. In 2012 IEEE Third International Conference on Sustainable Energy Technologies (ICSET) (pp. 196-199). IEEE. https://doi.org/10.1109/ICSET.2012.6357397

[19] Sharma, V., \& Chandel, S. S. (2013). Performance analysis of a $190 \mathrm{kWp}$ grid interactive solar photovoltaic power plant in India. Energy, 55, 476-485. https://doi.org/10.1016/j.energy.2013.03.075

[20] [20] Al Ali, M., \& Emziane, M. (2013). Performance analysis of rooftop PV systems in Abu Dhabi. Energy Procedia, 42 , 689-697. https://doi.org/10.1016/j.egypro.2013.11.071

[21] Bouzguenda, M., Al Omair, A., Al Naeem, A., AlMuthaffar, M., \& Wazir, O. B. (2014, March). Design of an off-grid $2 \mathrm{~kW}$ solar PV system. In 2014 Ninth International Conference on Ecological Vehicles and Renewable Energies (EVER) (pp. 1-6). IEEE. https://doi.org/10.1109/EVER.2014.6844001

[22] Yadav, P., Kumar, N., \& Chandel, S. S. (2015, April). Simulation and performance analysis of a $1 \mathrm{kWp}$ photovoltaic system using PVsyst. In 2015 International Conference on Computation of Power, Energy, Information and Communication (ICCPEIC) (pp. 0358-0363). IEEE. https://doi.org/10.1109/ICCPEIC.2015.7259481

[23] Irwan, Y. M., Amelia, A. R., Irwanto, M., Leow, W. Z., Gomesh, N., \& Safwati, I. (2015). Stand-alone photovoltaic (SAPV) system assessment using PVSYST software. Energy Procedia, 79, 596-603. https://doi.org/10.1016/j.egypro.2015.11.539

[24] Okello, D., Van Dyk, E. E., \& Vorster, F. J. (2015). Analysis of measured and simulated performance data of a $3.2 \mathrm{kWp}$ grid-connected PV system in Port Elizabeth, South Africa. Energy conversion and management, 100, 10-15. https://doi.org/10.1016/j.enconman.2015.04.064

[25] Tarigan, E., Djuwari, D., \& Kartikasari, F. D. (2015). Techno-economic simulation of a grid-connected PV system design as specifically applied to residential in Surabaya, Indonesia. Energy Procedia, 65, 90-99. https://doi.org/10.1016/i.egypro.2015.01.038 
[26] Matiyali, K., \& Ashok, A. (2016). Performance evaluation of grid connected solar PV power plant. In 2016 2nd International Conference on Advances in Computing, Communication, \& Automation (ICACCA)(Fall) (pp. 1-5). IEEE. https://doi.org/10.1109/ICACCAF.2016.7748989

[27] [27] Ashwini, K., Raj, A., \& Gupta, M. (2016, December). Performance assessment and orientation optimization of $100 \mathrm{kWp}$ grid connected solar PV system in Indian scenario. In 2016 International Conference on Recent Advances and Innovations in Engineering (ICRAIE) (pp. 1-7). IEEE. https://doi.org/10.1109/ICRAIE.2016.7939505

[28] Sharma, R., \& Gidwani, L. (2017, April). Grid connected solar PV system design and calculation by using PV* SOL premium simulation tool for campus hostels of RTU Kota. In 2017 International Conference on Circuit, Power and Computing Technologies (ICCPCT) (pp. 1-5). IEEE. https://doi.org/10.1109/ICCPCT.2017.8074315

[29] [29] Kumar, N. M., Kumar, M. R., Rejoice, P. R., \& Mathew, M. (2017). Performance analysis of $100 \mathrm{kWp}$ grid connected Si-poly photovoltaic system using PVsyst simulation tool. Energy Procedia, 117, 180-189. https://doi.org/10.1016/j.egypro.2017.05.121

[30] Mediratta, V., Bansal, K., Kuchhhal, P., \& Chandna, V. (2017). Design and Sizing of Decentralized Grid-Connected Solar Power Plant. In Proceeding of International Conference on Intelligent Communication, Control and Devices (pp. 741-746). Springer, Singapore. http://dx.doi.org/10.1007/978-981-10-1708-7_85

[31] Dondariya, C., Porwal, D., Awasthi, A., Shukla, A. K., Sudhakar, K., SR, M. M., \& Bhimte, A. (2018). Performance simulation of grid-connected rooftop solar PV system for small households: A case study of Ujjain, India. Energy Reports, 4, 546-553. https://doi.org/10.1016/j.egyr.2018.08.002

[32] Korsavi, S. S., Zomorodian, Z. S., \& Tahsildoost, M. (2018). Energy and economic performance of rooftop PV panels in the hot and dry climate of Iran. Journal of Cleaner Production,

174 ,

1204-1214. https://doi.org/10.1016/i.jclepro.2017.11.026

[33] Elamim, A., Hartiti, B., Haibaoui, A., Lfakir, A., \& Thevenin, P. (2018). Performance evaluation and economical analysis of three photovoltaic systems installed in an institutional building in Errachidia, Morocco. Energy Procedia, 147 ,

121-129. https://doi.org/10.1016/j.egypro.2018.07.041

[34] Akpolat, A. N., Dursun, E., Kuzucuoğlu, A. E., Yang, Y., Blaabjerg, F., \& Baba, A. F. (2019). Performance analysis of a grid-connected rooftop solar photovoltaic system. Electronics, $8(8)$

905. https://doi.org/10.3390/electronics8080905

[35] Kumar, N. M., Gupta, R. P., Mathew, M., Jayakumar, A., \& Singh, N. K. (2019). Performance, energy loss, and degradation prediction of roof-integrated crystalline solar PV system installed in Northern India. Case Studies in Thermal Engineering, 13, 100409. https://doi.org/10.1016/j.csite.2019.100409

[36] Dey, D., \& Subudhi, B. (2020). Design, simulation and economic evaluation of $90 \mathrm{~kW}$ grid connected Photovoltaic system. Energy Reports, 6, 1778-1787. https://doi.org/10.1016/j.egyr.2020.04.027

[37] Cristea, C., Cristea, M., Birou, I., \& Tîrnovan, R. A. (2020). Economic assessment of grid-connected residential solar photovoltaic systems introduced under Romania's new regulation. Renewable Energy, 162, 13-29. https://doi.org/10.1016/j.renene.2020.07.130
[38] Ali, H., \& Khan, H. A. (2020). Techno-economic evaluation of two $42 \mathrm{kWp}$ polycrystalline-Si and CIS thin-film based PV rooftop systems in Pakistan. Renewable Energy, 152, 347-357. https://doi.org/10.1016/j.renene.2019.12.144

[39] Do, T. N., Burke, P. J., Baldwin, K. G., \& Nguyen, C. T. (2020). Underlying drivers and barriers for solar photovoltaics diffusion: The case of Vietnam. Energy Policy, 144, https://doi.org/10.1016/j.enpol.2020.111561

[40] Hassan, M. U., Saha, S., \& Haque, M. E. A framework for the performance evaluation of household rooftop solar battery systems. International Journal of Electrical Power \& Energy Systems, 125, 106446. https://doi.org/10.1016/j.ijepes.2020.106446

[41] Phap, V., \& Nguyen, N. (2020). Feasibility Study Of Rooftop Photovoltaic Power System For A Research Institute Towards Green Building In Vietnam. EAI Endorsed Transactions on Energy Web, 7(26). http://dx.doi.org/10.4108/eai.7-1-2020.162825

[42] Sharma, S. K., Palwalia, D. K., \& Shrivastava, V. (2019). Performance Analysis of Grid-Connected $10.6 \mathrm{~kW}$ (Commercial) Solar PV Power Generation System. Applied Solar Energy, 55(5), 269281.https://doi.org/10.3103/S0003701X19050128

[43] Boxwell, M. (2019). The Solar Electricity Handbook-2017 Edition: A simple, practical guide to solar energy-designing and installing solar photovoltaic systems. Greenstream Publishing.

[44] Wai, R. J., Lin, C. Y., Huang, Y. C., \& Chang, Y. R. (2012). Design of high-performance stand-alone and gridconnected inverter for distributed generation applications. IEEE Transactions on Industrial Electronics, 60(4), 15421555. https://doi.org/10.1109/TIE.2012.2216232

[45] Khoury, J., Mbayed, R., Salloum, G., \& Monmasson, E. (2016). Design and implementation of a real time demand side management under intermittent primary energy source conditions with a PV-battery backup system. Energy and Buildings, 133, 122-130. https://doi.org/10.1016/j.enbuild.2016.09.036

[46] Retail Price For Household Electricity in Vietnam https://en.evn.com.vn/d6/gioi-thieu-d/RETAILELECTRICITY-TARIFF-9-28-252.aspx

[47] Thopil, G. A., Sachse, C. E., Lalk, J., \& Thopil, M. S. (2020). Techno-economic performance comparison of crystalline and thin film PV panels under varying meteorological conditions: A high solar resource southern hemisphere case. Applied Energy, 275, 115041. https://doi.org/10.1016/j.apenergy.2020.115041

[48] Pal, P., Mukherjee, V., Kumar, P., \& Makhatha, M. E. (2020). Pre-feasibility analysis and performance assessment of solar photovoltaic (PV) modules for the application of renewable power generation. Materials Today: Proceedings. https://doi.org/10.1016/j.matpr.2020.10.557

[49] Paulus, A., Arhun, S., Hnatov, A., Dziubenko, O., \& Ponikarovska, S. (2018, November). Determination of the best load parameters for productive operation of PV panels of series FS-100M and FS-110P for sustainable energy efficient road pavement. In 2018 IEEE 59th International Scientific Conference on Power and Electrical Engineering of Riga Technical University (RTUCON) (pp. 1-6). IEEE. https://doi.org/10.1109/RTUCON.2018.8659829

[50] Mathew, M., Kumar, N. M., \& i Koroth, R. P. (2018). Outdoor measurement of mono and poly c-Si PV modules and array characteristics under varying load in hot-humid tropical climate. Materials Today: Proceedings, 5(2), 34563464. https://doi.org/10.1016/j.matpr.2017.11.592 
[51] Mondol, J. D., Yohanis, Y. G., \& Norton, B. (2006). Optimal sizing of array and inverter for grid-connected photovoltaic systems. Solar energy, 80(12), 1517-1539. https://doi.org/10.1016/j.solener.2006.01.006

[52] Mermoud, A. (1995). Use and validation of PVSYST, a user-friendly software for PV-system design. In Thirteenth European Photovoltaic Solar Energy Conference. HS Stephens. https://archive-ouverte.unige.ch/unige:119365

[53] International Electrotechnical Commission. (1998). Photovoltaic system performance monitoring-guidelines for measurement, data exchange and analysis. IEC 61724.

[54] Remund, J. (2015). Accuracy of Meteonorm. A detailed look at the model steps and uncertainties.[online] Available at: http://www. meteonorm. com/images/uploads/downloads/Accuracy of Meteonorm 7. pdf [Accessed 21 Apr. 2016].

[55] Fath, K., Stengel, J., Sprenger, W., Wilson, H. R., Schultmann, F., \& Kuhn, T. E. (2015). A method for predicting the economic potential of (building-integrated) photovoltaics in urban areas based on hourly Radiance simulations. Solar energy, 116, 357-370. https://doi.org/10.1016/j.solener.2015.03.023

[56] Masters, G. M. (2013). Renewable and efficient electric power systems. John Wiley \& Sons.

[57] Sowe, S., Ketjoy, N., Thanarak, P., \& Suriwong, T. (2014). Technical and economic viability assessment of PV power plants for rural electrification in the Gambia. Energy Procedia, 52, 389-398. https://doi.org/10.1016/i.egypro.2014.07.091

[58] Ismail, E. A., \& Hashim, S. M. (2018, August). An economic evaluation of grid connected photovoltaic system for a residential house in Khartoum. In 2018 International Conference on Computer, Control, Electrical, and Electronics Engineering (ICCCEEE) (pp. 1-6). IEEE. https://doi.org/10.1109/ICCCEEE.2018.8515807

[59] Ouedraogo, B. I., Kouame, S., Azoumah, Y., \& Yamegueu, D. (2015). Incentives for rural off grid electrification in Burkina Faso using LCOE. Renewable Energy, 78, 573582. https://doi.org/10.1016/j.renene.2015.01.044

[60] Krauter, S., \& Rüther, R. (2004). Considerations for the calculation of greenhouse gas reduction by photovoltaic solar energy. Renewable Energy, 29(3), 345-355. https://doi.org/10.1016/S0960-1481(03)00251-9 